\title{
Transfer RNA comes of age
}

\author{
MICHAEL IBBA \\ Department of Microbiology, The Ohio State University, Columbus, Ohio 43210-1292, USA
}

The year the journal RNA was founded was slated by some in scientific publishing to be the year that one particular type of RNA's run in the spotlight would end. In 1995 I had recently started as a post-doc with Dieter Söll at Yale when he came into the lab to solemnly inform us all that an editor at a certain (S)cience journal had just told him "we won't be publishing any more tRNA papers." For a post-doc who had migrated across the Atlantic for the sole purpose of furthering his career by working on tRNA this was not great news, but at least the pizza was as good as promised in New Haven (if you need convincing, try the Italian and Veggie Bombs at Modern Apizza on State Street). Dieter consoled us by saying that plenty of other good journals were still interested in tRNA, plus there was this new journal "RNA" that had a whole bunch of great editors, many of whom had worked on tRNA themselves. Half a pie and a refreshing beverage or two later, my faith in tRNA was restored and it hasn't let me down since.

Transfer RNA (tRNA) was one of the first functional RNAs worked on in any detail, starting life in the 1950s as the "soluble RNA" discovered by Paul Zamecnik and Mahlon Hoagland. The key role of tRNA in genetic decoding drew in many great researchers, and it played a key role in numerous milestones in molecular biology over the next few decades. By 1995 tRNA had featured in major breakthroughs on the genetic code, RNA secondary structure, RNA three-dimensional structure, protein-RNA recognition, ribonucleoprotein structure, genetic suppression, catalytic RNA, RNA processing, riboswitches, protein synthesis, and RNA modification, to name just a few. So why, after all this success, was tRNA's popularity seen by some to be on the verge of decline in 1995 ? In part tRNA was a victim of its own success. Many of the technical approaches that had been pioneered with tRNA were starting to be applied to what were seen to be bigger, better, and more important RNAs about which we knew less. And to be honest, some of these RNAs were more interesting than tRNA at the time. As a post-doc at Yale in the mid-1990s I learned to appreciate first hand the bigger RNA world. To name just a few examples, I got one of the first glimpses at the structure of a group I ribozyme, learned about

Corresponding author: ibba.1@osu.edu

Article and publication date are at http://www.rnajournal.org/cgi/doi/10. 1261/rna.050179.115. Freely available online through the RNA Open Access option. the amazing world of snRNAs, and had friends who were helping to solve the crystal structure of the ribosome, all breakthroughs that continue to have far-reaching impacts today on the field of biology. So in the face of all these advances with bigger RNAs, how did the Söll lab and our little tRNAs manage to keep a place in Yale's RNA club? Aside from picking up the pizza tab, the advent of whole genome sequencing and the application of genomics expand our research horizons in ways we could never have envisaged at the time.

Before 1995 much of our knowledge of tRNA was mostly based on work from a handful of model organisms such as Escherichia coli and yeast, to name two of the usual suspects. When the first bacterial genome, from Haemophilus infleun$z a e$, was published in 1995 genomics provided a "nice" (in the "you're nice, but" sense) conformation of predictions on tRNA gene structure, but no real surprises. That all changed not long afterward when the first archaeal genome sequences started to appear, and several of what were assumed to be essential components of the translation machinery were missing. Working from this and many other genome sequences that came out shortly afterward, we and others in the field have since discovered an incredible diversity of new tRNAdependent pathways that continue to expand our understanding of translation, physiology, and evolution. At around the same time, this new appreciation of the unexpected diversity of tRNA structure and function also played a part in early breakthroughs in the now flourishing field of synthetic biology by enabling the design of systems for protein synthesis with non-natural amino acids. The most recent developments in tRNA molecular biology have proved critical for the successful construction of increasingly elaborate synthetic genetic codes and redesigned genomes, advances that will continue to have a significant impact on biology for years to come.

One major impact of genomics was to broaden our understanding of tRNA's many functions, in effect redefining Crick's adaptor hypothesis to encompass roles both inside and outside translation. The other significant change in the last two decades has been the growing realization that rather than simply being a passive adaptor, tRNA can also function as a major regulator of gene expression. The first indications

(C) 2015 Ibba This article, published in RNA, is available under a Creative Commons License (Attribution-NonCommercial 4.0 International), as described at http://creativecommons.org/licenses/by-nc/4.0/. 
that there was more to tRNA than meets the eye came when sequencing uncovered much larger numbers of tRNA genes than expected in eukaryotic genomes. E. coli contains just over 80 tRNA genes, providing a reasonable degree of redundancy for genetic decoding. Sequencing revealed that yeast had more than 280 and humans over 500 tRNA genes. Initially these unexpectedly high gene numbers were seen as a reflection of the increasing complexity of eukaryotic genomes, and some also raised doubts that all these genes were normally expressed. In the years that followed these first sequencing-based discoveries, advances in genome-wide technologies have started to show how these numerous tRNA genes function in the regulation of gene expression. Monitoring of the cellular aminoacylation status for all tRNAs and the ability to rapidly determine global changes in post-transcriptional RNA modification patterns have revealed a whole new level of tRNA dynamics few in the field could have anticipat- ed a decade ago. It is now becoming clear that stress and other stimuli lead to changes in the expression levels, aminoacylation status, and modification patterns of specific tRNAs, which in turn leads to changes in gene expression at the level of translation. Such changes in tRNA populations are emerging as a key mechanism by which cells regulate gene expression and cellular physiology, for example in proliferating versus differentiating cells.

Twenty years on, tRNA seems to be everywhere, playing key roles in advances at the forefront of synthetic, molecular, and structural biology. The newfound appreciation of tRNA dynamics in particular is bringing a lot of excitement to the field, and it is clear that to date we've only started to scratch the surface in our understanding of tRNA biology. To paraphrase a tired but apt cliché, tRNA's demise was greatly exaggerated in 1995. Just like the journal RNA, the tRNA field has a bright and vibrant future ahead of it. Here's to the next 20 years. 

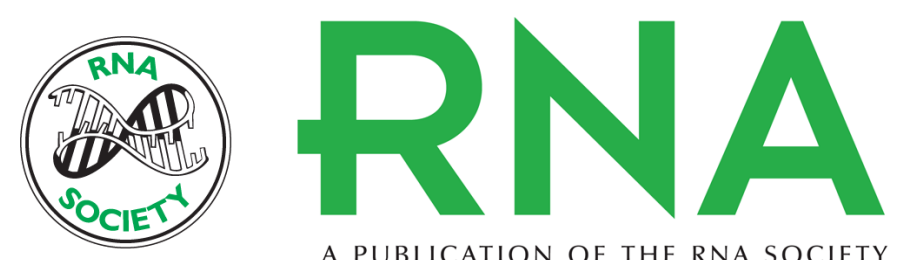

A PUBLICATION OF THE RNA SOCIETY

\section{Transfer RNA comes of age}

Michael Ibba

RNA 2015 21: 648-649

Open Access Freely available online through the RNA Open Access option.

Creative This article, published in $R N A$, is available under a Creative Commons License

Commons (Attribution-NonCommercial 4.0 International), as described at

License http://creativecommons.org/licenses/by-nc/4.0/.

Email Alerting Receive free email alerts when new articles cite this article - sign up in the box at the Service top right corner of the article or click here.

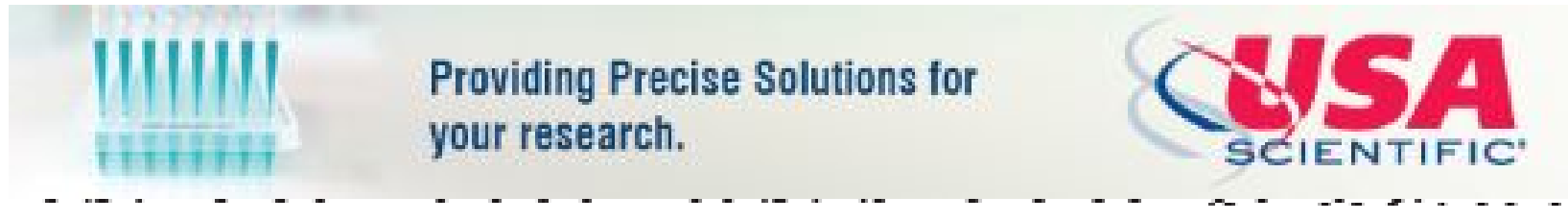

To subscribe to $R N A$ go to:

http://rnajournal.cshlp.org/subscriptions

(C) 2015 Ibba; Published by Cold Spring Harbor Laboratory Press for the RNA Society 